\title{
High Functional Diversity is Related to High Nitrogen Availability in a Deciduous Forest - Evidence from a Functional Trait Approach
}

\author{
Markus Bernhardt-Römermann • \\ Christine Römermann • Valério DePatta Pillar • \\ Thomas Kudernatsch • Anton Fischer
}

C The Author(s) 2010. This article is published with open access at Springerlink.com

\begin{abstract}
The current study tested the assumption that floristic and functional diversity patterns are negatively related to soil nitrogen content. We analyzed 20 plots with soil $\mathrm{N}$-contents ranging from $0.63 \%$ to $1.06 \%$ in a deciduous forest near Munich (Germany). To describe species adaptation strategies to different nitrogen availabilities, we used a plant functional type (PFT) approach. Each identified PFT represents one realized adaptation strategy to the current environment. These were correlated, next to plant species richness and evenness, to soil nitrogen contents. We found that $\mathrm{N}$-efficient species were typical for low soil nitrogen contents, while Nrequiring species occur at high $\mathrm{N}$-contents. In contrast to our initial hypotheses, floristic and functional diversity measures (number of PFTs) were positively related
\end{abstract}

\footnotetext{
M. Bernhardt-Römermann ( $\bowtie)$

Department of Silviculture and Forest Ecology of the Temperate Zones, Georg-August University Göttingen, 37077 Göttingen, Germany

e-mail: Markus.Bernhardt@forst.uni-goettingen.de

\section{Römermann}

Institute of Physical Geography, Johann-Wolfgang-Goethe University Frankfurt, 60438 Frankfurt, Germany

e-mail: roemermann@em.uni-frankfurt.de
}

\section{D. Pillar}

Departamento de Ecologia, Universidade Federal do Rio Grande do Sul, Porto Alegre,

RS 91540-000, Brazil

e-mail: vpillar@ufrgs.br

T. Kudernatsch $\cdot$ A. Fischer

Department of Ecology - Geobotany, TU München, 85354 Freising, Germany

T. Kudernatsch

e-mail: Kudernatsch@wzw.tum.de

\section{A. Fischer}

e-mail: a.fischer@wzw.tum.de 
to nitrogen content in the soil. Every functional group has its own adaptation to the prevailing environmental conditions; in consequence, these functional groups can co-exist but do not out-compete one another. The increased number of functional groups at high $\mathrm{N}$-contents leads to increased species richness. Hence, for explaining diversity patterns we need to consider species groups representing different adaptations to the current environmental conditions. Such co-existing ecological strategies may even overcome the importance of competition in their effect on biodiversity.

Keywords Life history traits $\cdot$ Nitrogen heterogeneity hypothesis $\cdot$ Nitrogen homogeneity hypothesis · Plant functional types (PFT) · Species evenness · Species richness

Plant nomenclature Wisskirchen and Haeupler (1998) for vascular plants; Koperski et al. (2000) for bryophytes

\section{Introduction}

Nitrogen as one of the most important plant nutrients has been the focus of many studies on ecosystem response. In industrialized and densely inhabited countries, nitrogen deposition is one of the most important factors influencing ecosystems because fertilizer use became common: The total atmospheric deposition of reduced nitrogen or nitrogen oxides to terrestrial ecosystems has increased from $17 \mathrm{Tg}$ N/year in 1860 to $64 \mathrm{Tg} \mathrm{N} /$ year in the 1990s (Galloway et al. 2004). However, during the last decades, measurements of nitrogen deposition in Central Europe show a slight decrease in nitrogen loads per year (Meesenburg et al. 2009), though the actual levels are still greater than the critical loads given by Bobbink and Roelofs (1995). As a consequence of nitrogen deposition, especially in nitrogen-limited ecosystems, changes have occurred in the vegetation composition (Bobbink et al. 1998; Smart et al. 2003; Bernhardt-Römermann et al. 2006a; Römermann 2006, Römermann et al. 2008). Because nitrogen deposition peaks in areas with high human populations, there is a high risk for nitrogen saturation in Central Europe, particularly in nitrogenlimited ecosystems such as forests (Tamm 1991).

Looking at biodiversity changes in forest ecosystems, the herbaceous layer is of outstanding interest due to its higher species richness in comparison to the tree layer. Furthermore, it responds more easily and quickly to changes in N-deposition compared to trees. Trees respond to increased N-deposition with increased growth rates (e.g., Emmett 1999; Sonnleitner et al. 2001), but with slow changes in species composition (Bernhardt-Römermann et al. 2006b).

In a review Gilliam (2006) concluded that the response of the forest herbaceous layer to increased nitrogen availability presents the following general patterns: $i$ ) initial increase in cover of the herb layer as a whole; $i i$ ) decrease in species richness due to loss of many $\mathrm{N}$-efficient species; iii) decrease in species evenness due to increasing dominance of few high $\mathrm{N}$-requiring species, and $i v$ ) decline in forest biodiversity as a result of decreases in both species richness and evenness. As these predictions are general patterns of ecosystem response, it should be possible to find 
these either in time (assuming an increase in $\mathrm{N}$-deposition and therefore $\mathrm{N}$-availability) or looking at spatial gradients. By choosing an existing gradient of nitrogen availability, in the current study we test the abovementioned changes in species diversity in a deciduous forest in Germany (Bernhardt-Römermann et al. 2007).

To learn more about these patterns of vegetation response, a plant functional type approach (PFT) was used. Such an approach is based on the assumption that plants with similar ecologically relevant traits respond to environmental changes in comparable ways (McIntyre et al. 1995). A trait is called functional when it impacts plant fitness indirectly via its effects on growth, reproduction, and survival. If the trait shows responses to changes in environmental conditions it is called a response trait; the values or modality taken by a trait at a point of an environmental gradient is called an attribute (Violle et al. 2007). A group of functional traits is called a plant functional type (PFT), but to be ecological meaningful each PFT should contain the most parsimonious number of traits only (as less traits as possible, but as much as needed; Keith et al. 2007; Bernhardt-Römermann et al. 2008). Using such PFTs we can estimate which functional trait composition is the result of differences in nitrogen availability on the estimated nitrogen gradient. Hence, the applied PFT approach can be used to learn more about patterns of biodiversity: different PFTs represent different adaptations of the co-occurring plant species to the current environmental conditions (complementarity of resource use; Díaz and Cabido 2001). Thus, we may explain high species richness by a high number of PFTs. Following Gilliam (2006) a higher number of PFTs should occur at nitrogen-poor situations in comparison to N-rich situations.

\section{Material and Methods}

\section{Study Area}

The study area, called Echinger Lohe, is located northeast of Munich $\left(11^{\circ} 43^{\prime} \mathrm{E}\right.$, $47^{\circ} 55^{\prime} \mathrm{N}, 465 \mathrm{~m}$ a.s.1.). It is a small deciduous forest of approximately 24 ha, which is surrounded by intensively used farmland. The mean annual temperature is approximately $9^{\circ} \mathrm{C}$ and the average annual rainfall about $800 \mathrm{~mm}$. The Echinger Lohe is situated on the "Münchener Schotterebene", a plain that was formed by homogeneously deposited gravel at the end of the last ice age. Due to intensive agriculture in the vicinity of the forest, the background level of nitrogen pollution is about 15-20 kg/ha (Bayerische Landesanstalt für Wald und Forstwirtschaft 2005). The vegetation type can be characterized as a Quercus petraea-Carpinus betulus forest with Acer pseudoplatanus on pararendzina soil.

\section{Vegetation Sampling}

To characterize the actual vegetation composition of the Echinger Lohe, 20 randomly distributed relevés of $15 \mathrm{~m} \times 15 \mathrm{~m}$ each were carried out in 2003 (the distance of each relevé is at least $40 \mathrm{~m}$ to footpaths or forest edges). This relevé size is recommended by Westhoff and van der Maarel (1973) for sampling the forest floor vegetation. 
Covers of vascular plants and bryophytes were estimated using the BraunBlanquet method (1964) with classes following Pfadenhauer et al. (1986; +: <1\%; 1a: $1 \%-3 \%$; 1b: 3\%-5\%; 2a: 5\%-15\%; 2b: 15\%-25\%; 3: 25\%-50\%; 4: 50\%-75\%; 5: $75 \%-100 \%$ ) and divided into herb, shrub, and tree layer. Additionally the overall cover of the herb layer was estimated in the field (using a percentage scale divided into 5\% interval classes). For data analyses, the cover of each species was transformed into the mean value of the limits in the corresponding class.

\section{Estimation of the Nitrogen Gradient}

Three soil samples were taken from the Ah-horizon of each relevé and pooled for further analyses to characterize the herb layer's main rooting space. These samples were analyzed following the German standard method for analyses of forest soils (Bodenzustandserhebung im Wald- BZE; Bundesministerium für Ernährung Landwirtschaft und Forsten 1994) for $\mathrm{N}, \mathrm{C}, \mathrm{pH}\left(\mathrm{H}_{2} \mathrm{O}\right), \mathrm{NH}_{4}{ }^{+}, \mathrm{NO}_{3}{ }^{-}, \mathrm{Cl}^{-}, \mathrm{H}_{2} \mathrm{PO}_{4}^{-}$, $\mathrm{SO}_{4}{ }^{2-}, \mathrm{Mg}^{2+}, \mathrm{Ca}^{2+}, \mathrm{K}^{+}, \mathrm{Na}^{+}, \mathrm{Al}^{3+}, \mathrm{Fe}^{2+}$, and $\mathrm{Mn}^{2+}$. Additionally, the thickness of the Ah-horizon was reported.

To characterize the three vegetation types defined by a cluster analysis, dry nitrogen deposition $\left(\mathrm{NH}_{3}\right.$ and $\mathrm{NO}_{2}$ ) was measured using passive samplers (one sampler per vegetation type in 2004). Wet deposition was calculated from the bulk precipitation in an adjacent non-wooded area. The potential nitrogen deposition was calculated by adding values of dry and wet deposition (see Bernhardt-Römermann et al. 2006a).

\section{Estimation of Differences in Species Composition}

The vegetation data from the 20 relevés were clustered into groups based on differences in their floristic composition. Relative Euclidean Distance and Ward's method were applied on transformed vegetation data following the formula $y=x^{0.25}$ (Wildi 1986), to reduce the weight of dominant species. Each of these vegetation types was characterized by its typical species set by the use of an indicator species analysis (ISA; Dufrene and Legendre 1997). An indicator species analysis assigns indicator values for each species, based on the degree to which they discriminate among groups. The indicator values (IV) range from zero (no indication) to 100 (perfect indication). For each indicator value a randomization test is used to evaluate its statistical significance. The null hypothesis is that the observed IV is no larger than would be expected by chance (i.e., that the species has no indicator value). All these statistics were done using the program PcOrd 5.21 (McCune and Mefford 1999).

Diversity indices (species richness and species evenness) and herb-cover were analyzed. These parameters were calculated including all herbaceous and bryophyte species. We calculated Pearson's product-moment correlations between the abovementioned vegetation parameters and the soil nitrogen content and tested for differences between vegetation groups using R 2.9.0 ( $\mathrm{R}$ Development Core Team 2009) randomization tests. 1,000 randomized samples were taken and the difference to the observed (measured) mean was calculated; if random samples show in less than $0.01 \%$ of all permutations a mean lower than the observed, a significant difference was assumed. 


\section{Plant Functional Types}

Using a plant functional type approach (PFT), the spatial nitrogen gradient was analyzed to identify nitrogen-induced vegetation differentiation. The analysis combined vegetation, trait, and environmental data and followed the numerical procedure by Pillar (Pillar 1999; Pillar and Sosinski 2003). Data were arranged in three different tables: $i$ ) relevés by species matrix, containing species percentage covers, $i$ i) species by traits matrix, and iii) relevés by environmental variables matrix.

Bryophytes were excluded from further analyses because trait data were not available. To characterize the environment, we used those parameters that described the differences in vegetation composition best: the $\mathrm{N}$-content of the soil and the thickness of the Ah-horizon (see below). The species descriptions by traits were taken from different trait databases. The traits cover different dimensions of plant life-history, including persistence and regeneration traits and are summarized in Table 1. All PFT analyses were carried out with the program SYNCSA 2.2.4 (Pillar 2004) using the polythetic clustering option. This program searches for the most relevant traits as part of the analyses themselves, therefore no further justification if the trait is relevant or not, is needed. In the following only a brief overview of the method is given, for details see Pillar and Sosinski (2003).

The iterative algorithm was used to evaluate all possible groups of species by cluster analyses with different subsets of traits. For each of these possible solutions the congruence between variation in vegetation composition and in the environment was measured using matrix correlation. The latter was calculated between the vegetation composition distances described by the species groups (using Chord's distance) and the site's distances described by the environment (using Euclidean distance after standardization of the variables by unit length). A trait subset was identified from all possible solutions for which the correlation (here called congruence) between the matrices was maximal.

In the second step, the PFTs defined by this optimal trait subset were used to describe the relevés, resulting in a PFT by relevés matrix. These results were visualized using a principal coordinates analysis (PCoA, Gower 1966, with Chord's distance).

For each plant functional type, the ecological performance was calculated by summing up the coverage of all species belonging to the respective PFT per relevé. Subsequently, the mean coverage per PFT was taken over all relevés. This value was relative with respect to the total cover of all species.

\section{Results}

As pointed out in Bernhardt-Römermann et al. (2007) the most important soil parameters for explaining the variance between the different vegetation types were the soil nitrogen content and the thickness of the main rooting horizon. The vegetation of the Echinger Lohe can be separated into three vegetation types (Bernhardt-Römermann et al. 2007). Table 2 shows the results of the indicator species analysis. It revealed that the following species characterize the different vegetation types: vegetation type 1 included the low-nitrogen tolerant (see Ellenberg $\mathrm{N}$-values in Table 2) species Carex montana, Rhytidiadephus triquetrus, Fragaria 
Table 1 Traits used for the description of species in the plant functional type analyses. Trait types (1 - nominal, 2 - ordinal), trait states and data sources are given

\begin{tabular}{|c|c|c|c|c|c|}
\hline Trait & Abr. & Type & Trait states & $\begin{array}{l}\text { State classes } \\
\text { according to }\end{array}$ & Data origin \\
\hline Plant height (max.) & MH & 2 & $\begin{array}{l}\text { 1: }<30 \mathrm{~cm} ; 2: 30-60 \mathrm{~cm} ; \\
\text { 3: }>60 \mathrm{~cm}\end{array}$ & Kleyer (1995) & Rothmaler (2002) \\
\hline Rosettes & RO & 1 & $\begin{array}{l}\text { 1: erosulate plant; } \\
\text { 2: hemirosette plant; } \\
\text { 3: rosette plant }\end{array}$ & $\begin{array}{l}\text { Klotz and } \\
\text { Kühn (2002) }\end{array}$ & Klotz et al. (2002) \\
\hline Leaf anatomy & $\mathrm{AN}$ & 1 & $\begin{array}{l}\text { 1: scleromorphic; } \\
\text { 2: mesomorphic; } \\
\text { 3: hygromorphic }\end{array}$ & $\begin{array}{l}\text { Klotz and } \\
\text { Kühn (2002) }\end{array}$ & $\begin{array}{l}\text { Kleyer (1995); } \\
\text { Klotz et al. (2002) }\end{array}$ \\
\hline Leaf persistence & LP & 1 & $\begin{array}{l}\text { 1: persistent green; } 2 \text { : spring } \\
\text { green; } 3 \text { : summer green }\end{array}$ & $\begin{array}{l}\text { Ellenberg et al. } \\
(2001)\end{array}$ & $\begin{array}{l}\text { Klotz et al. (2002); } \\
\text { BfN (2003) }\end{array}$ \\
\hline Leaf form & LF & 1 & $\begin{array}{l}\text { 1: grass-like; } 2 \text { : long leaf; } \\
\text { 3: simple; 4: full; 5: lobate; } \\
\text { 6: pinnatifid; 7: digitate; } \\
\text { 8: palmate; 9: pinnate; } \\
\text { 10: bipinnate }\end{array}$ & $\begin{array}{l}\text { Klotz and } \\
\text { Kühn (2002) }\end{array}$ & $\begin{array}{l}\text { Oberdorfer (2001); } \\
\text { Klotz et al. (2002) }\end{array}$ \\
\hline Vegetative spread & VS & 1 & $\begin{array}{l}\mathbf{1}:<100 \mathrm{~mm}, \text { CLOPLA1 } \\
\text { (numbers } 1,2,4,6,7,9, \\
\text { 12, 13, 15-19); 2: } \geq 100 \mathrm{~mm}, \\
\text { CLOPLA1 (numbers } 3,5, \\
8,10,11,14 \text { ) }\end{array}$ & Kahmen (2004) & Klimeš et al. (1997) \\
\hline Plant persistence & $\mathrm{PP}$ & 1 & $\begin{array}{l}\text { 1: annual; 2: perennial, not } \\
\text { clonal, CLOPLA1 (numbers 1, } \\
2,4,12,16-19) ; 3 \text { : perennial, } \\
\text { clonal, CLOPLA1 (numbers } 3 \text {, } \\
5-11,13-15 \text { ) }\end{array}$ & Kahmen (2004) & Klimeš et al. (1997) \\
\hline Seed mass & MA & 2 & $\begin{array}{l}\mathbf{1}: \leq 0.2 ; \mathbf{2}: 0.21-0.5 ; \mathbf{3}: 0.51-1 \\
\mathbf{4}: 1.01-2 ; \mathbf{5}: 2.01-10 ; \\
\mathbf{6}:>10(\mathrm{mg} / 1,000 \text { seeds })\end{array}$ & $\begin{array}{l}\text { Grime et al. } \\
\text { (1988) }\end{array}$ & Flynn et al. (2004) \\
\hline Pollination & $\mathrm{PO}$ & 1 & $\begin{array}{l}\text { 1: selfing; } 2 \text { : by insects; } \\
\text { 3: by wind }\end{array}$ & & $\begin{array}{l}\text { Klotz et al. (2002); } \\
\text { BfN (2003) }\end{array}$ \\
\hline Start of flowering & SF & 1 & $\begin{array}{l}\text { 1: before or in May; } 2 \text { : after } \\
\text { May }\end{array}$ & Kahmen (2004) & $\begin{array}{l}\text { Rothmaler (2002); } \\
\text { BfN (2003) }\end{array}$ \\
\hline $\begin{array}{l}\text { Duration of } \\
\text { flowering }\end{array}$ & DF & 1 & 1: $1-2$ months; $\mathbf{2}: \geq 3$ months & Kahmen (2004) & $\begin{array}{l}\text { Rothmaler (2002); } \\
\text { BfN (2003) }\end{array}$ \\
\hline
\end{tabular}

vesca, Rubus saxatilis, Convallaria majalis, and Vincetoxicum hirundinaria. Type 3, however, was characterized by the occurrence of species that are typical for high $\mathrm{N}$-availability (see Ellenberg N-values in Table 2): Corydalis cava, Asarum europaeum, Heracleum sphondylium, Arum maculatum, Allium carinatum, Elymus caninus, Stachys sylvatica, Gagea lutea, Aegopodium podagraria, Chaerophyllum aureum, Eurhynchium swartzii, Polygonum multiflorum, and Plagiomnium undulatum. For vegetation type 2 only Paris quadrifolia was found as a significant indicator species. These patterns and interpretations of the vegetation differentiation were consistent with the results of the soil analyses. As stressed by BernhardtRömermann et al. (2007) the actual gradient in vegetation differentiation was closely 
Table 2 Results of the indicator species analysis (ISA). Only non-tree species having significant indicator values are shown. For each species, its indicator value (IV) and typical vegetation type is reported. Additionally, Ellenberg-values for nitrogen $(\mathrm{N})$ are given

\begin{tabular}{lllll}
\hline Species & Type & IV & $P$-value & N \\
\hline Carex montana & 1 & 98.3 & 0.000 & 3 \\
Rhytidiadepus triquetrus & 1 & 87.8 & 0.005 & - \\
Fragaria vesca & 1 & 67.5 & 0.010 & 6 \\
Rubus saxatilis & 1 & 58.3 & 0.030 & 4 \\
Convallaria majalis & 1 & 79.2 & 0.037 & 4 \\
Vincetoxicum hirundinaria & 1 & 50.0 & 0.044 & 3 \\
Paris quadrifolia & 2 & 65.5 & 0.033 & 7 \\
Asarum europaeum & 3 & 87.5 & 0.000 & 6 \\
Heracleum sphondylium & 3 & 87.5 & 0.000 & 8 \\
Arum maculatum & 3 & 94.8 & 0.001 & 8 \\
Corydalis cava & 3 & 87.5 & 0.002 & 8 \\
Allium carinatum & 3 & 68.4 & 0.004 & 8 \\
Elymus caninus & 3 & 75.0 & 0.004 & 7 \\
Stachys sylvatica & 3 & 67.8 & 0.011 & 7 \\
Gagea lutea & 3 & 64.3 & 0.013 & 8 \\
Aegopodium podagraria & 3 & 61.3 & 0.028 & 9 \\
Chaerophyllum aureum & 3 & 50.0 & 0.042 & \\
Eurhynchium swartzii & 3 & 50.0 & 0.043 & 5 \\
Polygonum multiflorum & 3 & 58.8 & 0.043 & \\
Plagiomnium undulatum & 3 & 50.0 & 0.046 & \\
\hline & & & & \\
\hline
\end{tabular}

related to differences in soil nitrogen content (mean $\mathrm{N}$ content in $\% \pm$ s.e.; type 1 : $0.76 \pm 0.04$; type $2: 0.72 \pm 0.04$; type $3: 0.94 \pm 0.03$ ) and to thickness of the main rooting horizon (mean Ah-horizon thickness in $\mathrm{cm} \pm$ s.e.; type 1: $6.7 \pm 0.5$; type 2: 7.5 \pm 0.4 ; type $3: 11.6 \pm 0.7$ ); all other soil parameters were found to be irrelevant. Looking at the annual N-deposition, again an increase from vegetation type 1 to 3 was found (type 1: $17.6 \mathrm{~kg} / \mathrm{ha}$, type $2: 19.9 \mathrm{~kg} / \mathrm{ha}$; type $3: 21.5 \mathrm{~kg} / \mathrm{ha}$ ).

The results of the correlation analyses between herb layer cover, evenness, species richness and soil $\mathrm{N}$-content showed significant positive relationships for all three correlations (Table 3). Between the three vegetation types we found significant differences in herb layer cover, evenness, and species richness (Table 3). The herb layer cover continuously increased from vegetation type 1 to 3 . For evenness no differences between type 1 and 2 were found, whereas vegetation type 3 showed significantly higher values. Richness peaked in vegetation type 3 , but only in vegetation type 2 was it significantly lower.

\section{Plant Functional Types}

All solutions of possible trait combinations that characterize the different plant types included traits that were related to biomass development, plant persistence (for 
Table 3 Diversity indices and cover of the herb layer for the three vegetation types (1 - low; 2 - intermediate; 3 - high nitrogen availability). Additionally, correlations with $\mathrm{N}$-content of the soil are presented. Means and standard errors are given. Different letters indicate significant differences within each category

\begin{tabular}{|c|c|c|c|c|c|c|}
\hline & \multicolumn{3}{|c|}{$\begin{array}{l}\text { Correlation with soil N-content } \\
(\text { d.f. }=16)\end{array}$} & \multirow{2}{*}{$\begin{array}{l}\text { Vegetation type } 1 \\
(n=8) \\
\text { Mean } \pm \text { s.e. }\end{array}$} & \multirow{2}{*}{$\begin{array}{l}\text { Vegetation type } 2 \\
(n=4) \\
\text { Mean } \pm \text { s.e. }\end{array}$} & \multirow{2}{*}{$\begin{array}{l}\text { Vegetation type } 3 \\
(n=8) \\
\text { Mean } \pm \text { s.e. }\end{array}$} \\
\hline & $t$-value & $P$-value & $r$-value & & & \\
\hline Richness & 2.50 & 0.022 & 0.51 & $30.9 \pm 2.36(\mathrm{ab})$ & $24.5 \pm 2.84$ (a) & $33.3 \pm 1.39(b)$ \\
\hline Evenness & 2.27 & 0.036 & 0.47 & $0.49 \pm 0.03$ (a) & $0.48 \pm 0.06$ (a) & $0.63 \pm 0.03(b)$ \\
\hline Cover & 2.52 & 0.021 & 0.51 & $65.0 \pm 3.41$ (a) & $66.3 \pm 6.25(\mathrm{ab})$ & $77.5 \pm 2.67(b)$ \\
\hline
\end{tabular}

example plant height, leaf form or leaf persistence) or flowering traits (start or duration of flowering); see Table 4 for an overview of different solutions and included traits. Even though congruence differs only slightly between the first five solutions (Table 4), we included the second solution proposed by the algorithm in further analyses, because it represented the most parsimonious solution with respect to numbers of PFTs needed for describing the vegetation differentiation $(n=7)$. This combination contained the traits leaf persistence, plant height, start of flowering, and seed mass.

Figure 1 showed the results of the PCoA of the relevés described by the extracted PFTs. The relevés were arranged from lower to higher nitrogen availability, where axis one described the nitrogen availability (correlation with soil N-content: $r^{2}=0.82$, $P<0.001)$. The performances of PFTs number 2, 3, 5, and 6 were associated with that gradient. From these, PFTs number 2, 3, and 5 formed a response group to high nitrogen availability, whereas PFT 6 characterized lower nitrogen contents (Fig. 1 and Table 5). The other PFTs (1, 4 and 7) show no response to that N-gradient and were omitted from further analyses.

The trait states of these four responding PFTs were indicated in Table 5. The plants of PFTs 2 and 5 were tall and flower late in the year. Those of PFT 2 were permanent green with seed masses between 1 and $2 \mathrm{mg}$, whereas PFT 5 contained summer green plants with lighter seeds (0.5 to $1 \mathrm{mg})$. Differently, the plants of PFT

Table 4 Trait subsets with highest values of congruence between the vegetation composition described by plant functional types with corresponding plant traits and the relevé sites described by the environmental variables, soil N-content and thickness of the Ah-horizon. Only optimal numbers of PFTs are presented. See Table 2 for explanation of trait abbreviations. The trait set used for further analyses is indicated by bold letters

\begin{tabular}{lllllllllll}
\hline Number & Congruence & No. of PFTs & \multicolumn{2}{l}{ Subset of traits } & & & & & \\
\hline 1 & 0.701 & 12 & MH & MA & PP & DF & & & \\
$\mathbf{2}$ & $\mathbf{0 . 6 8 4}$ & $\mathbf{7}$ & LP & MH & MA & SF & & & \\
3 & 0.675 & 12 & LP & AN & MH & MA & SF & DF & LF \\
4 & 0.671 & 11 & LP & MH & MA & SF & DF & & \\
5 & 0.671 & 11 & LP & MH & SF & DF & & & \\
\hline
\end{tabular}


Table 5 Trait states of the seven PFTs found by the matrix correlation. For the analysis the traits leaf persistence, height of plant, start of flowering, and seed mass were used. Those PFTs found best for describing the environmental gradient using the PCoA (Fig. 1) were marked in bold letters. PFTs showing a positive correlation with the first axis of the PCoA were grouped together in the response group 1 (high nitrogen availability), and those with a negative correlation were put into response group 0 (low nitrogen availability)

\begin{tabular}{|c|c|c|c|c|c|}
\hline PFT & Response group & Leaf persistence & Height of plant & Seed mass & Start of flowering \\
\hline 1 & & persistent green & $\leq 30 \mathrm{~cm}$ & $1-2 \mathrm{mg}$ & before or in May \\
\hline 2 & 1 & persistent green & $>60 \mathrm{~cm}$ & 1-2 mg & after May \\
\hline 3 & 1 & spring green & $\leq 30 \mathrm{~cm}$ & $2-10 \mathrm{mg}$ & before or in May \\
\hline 4 & & summer green & $30-60 \mathrm{~cm}$ & $2-10 \mathrm{mg}$ & after May \\
\hline 5 & 1 & summer green & $>60 \mathrm{~cm}$ & $0.5-1 \mathrm{mg}$ & after May \\
\hline 6 & $\mathbf{0}$ & summer green & $30-60 \mathrm{~cm}$ & 2-10 mg & before or in May \\
\hline 7 & & persistent green & $>60 \mathrm{~cm}$ & $1-2 \mathrm{mg}$ & before or in May \\
\hline
\end{tabular}

3 were small, spring green, early-flowering, and had heavy seeds. PFT 6, the only representative of the response group 0 (i.e., indicating low nitrogen availability), comprised summer green, medium-sized species that flower early in the year and had heavy seeds. In total, more than $74 \%$ of all herbaceous species occurring in the Echinger Lohe were described using one of these PFTs (Table 6).

\section{Discussion}

The results of the current study clearly showed that the vegetation differentiation in the Echinger Lohe is closely related to a gradient in nitrogen availability. Next to soil $\mathrm{N}$-content we found differences in the thickness of the Ah-horizon that are related to differences in plant available water. However, it is well known from literature (e.g., Ellenberg 1996) that additional water or nutrient supply has a similar effect on plant growth, as both induce advanced nutrient uptake (if there is a sufficient minimum of water available). Thus, the influence of the two factors, soil $\mathrm{N}$-content and increased

Fig. 1 Ordination diagram (PCoA) of the forest floor vegetation described using traits. Larger nitrogen availabilities are indicated by larger circles. Matrix: Seven PFTs defined by the four traits in bold in Table 4 by 20 relevés. Axis 1 : eigenvalue $=1.52$, explained variance $=58.0 \%$; axis 2 : eigenvalue $=0.49$, explained variance $=18.6$; correlation threshold: $r=0.6$. For description of the PFTs see Table 5

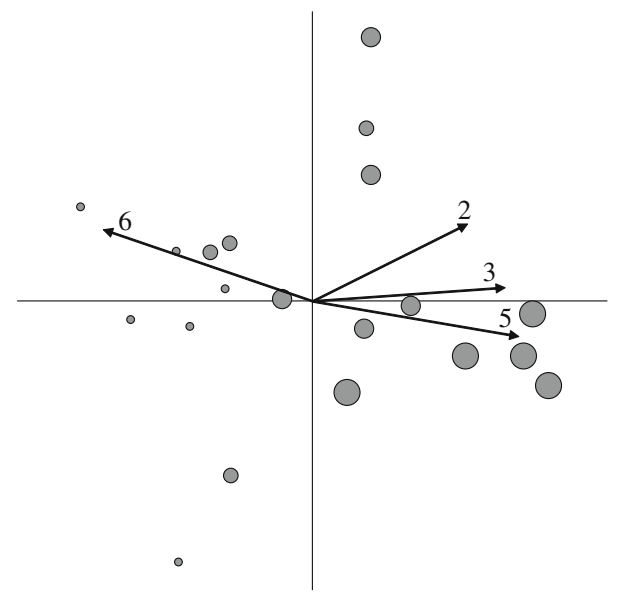


Table 6 Species belonging to the different plant functional types (PFT). Numbers of PFTs and response groups correspond to those given in Table 5. Additionally, the relative ecological performance (REP, in \% of mean total vegetation cover) is given for each PFT

\begin{tabular}{|c|c|c|c|}
\hline PFT & Response group & Species & REP \\
\hline 2 & 1 & Allium carinatum, Lamium montanum, Geum urbanum & 11.1 \\
\hline 3 & 1 & $\begin{array}{l}\text { Anemone nemorosa, Arum maculatum, Corydalis cava, } \\
\text { Gagea lutea, Ranunculus ficaria }\end{array}$ & 8.2 \\
\hline 5 & 1 & $\begin{array}{l}\text { Brachypodium sylvaticum, Campanula trachelium, } \\
\text { Aegopodium podagraria, Allium scorodoprasum subsp. } \\
\text { rotundum, Lilium martagon, Stachys sylvatica, Poa } \\
\text { nemoralis, Chaerophyllum aureum, Elymus caninus, } \\
\text { Heracleum sphondylium }\end{array}$ & 17.7 \\
\hline 6 & 0 & $\begin{array}{l}\text { Carex montana, Convallaria majalis, Lamium maculatum, } \\
\text { Maianthemum bifolium, Melica nutans, Polygonatum } \\
\text { multiflorum, Paris quadrifolia, Viola hirta, Vincetoxicum } \\
\text { hirundinaria, Primula veris, Viola mirabilis, Mercurialis } \\
\text { perennis, Ranunculus lanuginosus }\end{array}$ & 26.7 \\
\hline
\end{tabular}

water availability, cannot be separated, but both are clearly related to nutrient uptake (Bernhardt-Römermann et al. 2007).

As already outlined in the introduction, vegetation development under increased nitrogen deposition and, therefore, availability can be divided into several steps: First, an increase in total vegetation cover, followed by a decrease of the nitrogen-efficient species (which are typical for conditions with low nitrogen availability) can be expected (Gilliam 2006). When describing the development of the ecosystems under increased nitrogen deposition, Gilliam (2006) assumed high species richness in the original stage, including species on N-poor and N-rich soils. These species coexist due to the spatial heterogeneity in nitrogen availability (nitrogen heterogeneity hypothesis: Ricklefs 1977; Tilman 1984; Rosenzweig and Abramsky 1993; Tilman and Pacala 1993). The increase in total vegetation cover is linked to the removal of the growth-limiting factor nitrogen, i.e., additional nitrogen is added to the system. Decreasing numbers of nitrogen efficient species can be explained by the increase of $\mathrm{N}$-requiring species that out-compete N-efficient species (Diekmann and FalkengrenGrerup 2002). The results of the current study are consistent with the described development because we could show a close positive relationship between vegetation cover and $\mathrm{N}$-content of the soil. Furthermore, vegetation type 1, which is typical for nitrogen-poor situations, is characterized by several N-efficient species (here indicated by Ellenberg $\mathrm{N}$-indicator values).

Subsequently, Gilliam (2006) suggested a decline in evenness due to the dominance of relatively few N-requiring species. Together with the decrease in N-efficient species, this leads finally to reduced biodiversity (in richness and evenness). Our results show a clear differentiation in species typical for nitrogen-rich and poor environments; under poor conditions N-efficient species dominated, in soils with a high nitrogen content N-requiring species dominated. Nevertheless, we did not find a decrease in total species richness and evenness with increasing N-content; rather we found a positive relationship between $\mathrm{N}$-content and species richness as well as evenness. We can explain this discrepancy to the aforementioned predictions of 
Gilliam (2006) using a functional trait approach, as life-history traits of species are strongly related to the processes of vegetation differentiation (Diekmann and Falkengren-Grerup 2002; Lavorel and Garnier 2002).

Assuming that the assemblage of species in most forest ecosystems is mainly determined by competition and stress tolerance (Grime 1979), ecosystems contain different plant strategies to compete for ecologically relevant resources. Different functional traits can be seen as strategies of resource use in which species of different PFTs show a higher degree of complementarity than those of the same PFT (Díaz and Cabido 2001). The more different PFTs co-occur in an ecosystem, the more ecologically relevant strategies co-exist and the higher the diversity may be (Mason et al. 2005). Nevertheless, most species are not equally distributed in their dominance patterns in ecosystems (Wilson and Agnew 1992; Grime 1998). The meaning of several realized strategies becomes even more relevant if these are dominated by only a few species: Evenness largely depends on the number of plant functional types under certain environmental conditions, i.e., in this case on nitrogen stages (Díaz and Cabido 1997; Hector et al. 1999; Chapin et al. 2000; Loreau et al. 2001). In the current study the response group 1, characterizing vegetation of high nitrogen availability, is composed of three PFTs. In comparison, response group 0 , which is typical for nitrogen-poor conditions, consists of only one PFT. Within response group 1, it was possible to identify three main strategies: The plants of the first two strategies are described by two PFTs (PFT 2 and 5); both represent tall, persistent or summer-green species that flower during the summer. In contrast, plants of the second strategy (PFT 3) are small species that start flowering early in spring. As also shown by Diekmann and Falkengren-Grerup (2002), tall species in the herb layer benefit from high amounts of nitrogen; for these species, the decreased light conditions (when the tree layer is foliated) can be compensated by better nutrient supply (Peace and Grubb 1982; Peace 1984). The small species belonging to PFT 3 can also be found in nutrient-rich forests (Al-Mufti et al. 1977; Rogers 1982; Host and Pregitzer 1991; Rothstein and Zak 2001), showing high rates of photosynthesis depending on high water and nutrient availability (Grime 1979). These species, however, evade competition by finishing their life cycle before the start of the foliation of the trees.

Within response group 0 (stands with lower levels of plant-available nitrogen) only one single PFT could be identified, which is characterized by medium-sized and summer-green plant species. Because of the lower thickness of the soil layer, dryness during summer is common (personal observation) and nitrogen availability is limited, which causes low cover and height of the vegetation. Stress is the most relevant factor for this vegetation type, whereas competition for growing space or light is less important; the forests are dominated by summer-green or persistent species (Grime 1994).

The PFT-approach used in the current study allows us to get information on how plant species use different strategies to compete for environmental resources. High species richness and species evenness under nitrogen-rich conditions can be clearly attributed to the higher number of functional adaptations to the current environment: As the number of PFTs increases, the species number increases, but the relative performance of each PFT decreases (the relative performance of each of the three PFTs under nutrient-rich conditions: $<18 \%$ vs relative performance of the PFT 6 
under nutrient-poor conditions: $26.7 \%$; see Table 6). Taking into account that each PFT is dominated by a few species (i.e., has a relatively low evenness) it becomes clear that the co-existence of several PFTs involves at the same time a co-existence of several "dominant" plant species: The higher biodiversity (richness as well as evenness) under nitrogen-rich conditions is strongly related to a higher variety of strategy types.

Thus, our results clearly showed contrasting results with respect to Gilliam's (2006) hypotheses: he hypothesized that chronically elevated nitrogen deposition leads to a decline in biodiversity due to a decrease of the spatial heterogeneity of nitrogen (nitrogen homogeneity hypothesis); in other words: nitrogen is made uniformly available in contrast to patchiness in more oligotrophic situations. Under these conditions of increased $\mathrm{N}$-deposition, vegetation changes are due to a switch from a coexistence of strong and weak competitors to a dominance of highly competitive species only. However, in the current study we found at high nitrogen availability an increased number of strategies of adaptation to the current environmental conditions - co-existence of species is possible due to a differentiation in use of ecological relevant recourses. Such co-existing ecological strategies may overcome the importance of competition in their effect on biodiversity.

Acknowledgements This work was funded by the Bavarian State Ministry of the Environment, Health, and Consumer Protection. We thank Simon Östreicher, Thomas Wiedenmann and the lab-team of the working-group of Prof. Dr. Axel Göttlein for help in the field and for analyzing soil samples, and Gina G. Lopez for language editing. Prof. Dr. Wolfgang Schmidt and three anonymous reviewers gave many useful comments on earlier drafts of the manuscript.

Open Access This article is distributed under the terms of the Creative Commons Attribution Noncommercial License which permits any noncommercial use, distribution, and reproduction in any medium, provided the original author(s) and source are credited.

\section{References}

Al-Mufti MM, Sydes CL, Furness SB, Grime JP, Band SR (1977) Quantitative-analysis of shoot phenology and dominance in herbaceous vegetation. $J$ Ecol 65:759-791

Bayerische Landesanstalt für Wald und Forstwirtschaft (2005) Waldzustandsbericht 2004. Bayerisches Staatsministerium für Landwirtschaft und Forsten, Freising

Bernhardt-Römermann M, Kudernatsch T, Pfadenhauer J, Kirchner M, Jakobi G, Fischer A (2006a) Changed vegetation composition in coniferous forests near to motorways in Southern Germany: the effects of traffic-born pollution. Environm Pollut 143:572-581

Bernhardt-Römermann M, Östreicher S, Fischer A, Kudernatsch T, Pfadenhauer J (2006b) Das GalioCarpinetum im Münchener Raum - Ergebnis früherer Bewirtschaftung? Tuexenia 26:27-36

Bernhardt-Römermann M, Kudernatsch T, Pfadenhauer J, Kirchner M, Jakobi G, Fischer A (2007) Longterm effects of nitrogen-deposition on vegetation in a deciduous forest near Munich, Germany. Appl Veg Sci 10:399-406

Bernhardt-Römermann M, Römermann C, Nuske R, Parth A, Klotz S, Schmidt W, Stadler J (2008) On the identification of the most suitable traits for plant functional trait analyses. Oikos 117:1533-1541

BfN (2003) Bundesamt für Naturschutz, Floraweb. Available at: http://www.floraweb.de/

Bobbink R, Roelofs JGM (1995) Nitrogen critical loads for natural and semi-natural ecosystems: The empirical approach. Water Air Soil Pollut 85:2413-2418

Bobbink R, Hornung M, Roelofs JGM (1998) The effects of air-borne nitrogen pollutants on species diversity in natural and semi-natural European vegetation. J Ecol 86:717-738

Braun-Blanquet J (1964) Pflanzensoziologie - Grundzüge der Vegetationskunde. Springer Verlag, Wien 
Bundesministerium für Ernährung, Landwirtschaft und Forsten (1994) Bundesweite Bodenzustandserhebung im Wald (BZE), Bonn

Chapin FS, Zavaleta ES, Eviner VT, Naylor RL, Vitousek PM, Reynolds HL, Hooper DU, Lavorel S, Sala OE, Hobbie SE, Mack MC, Diaz S (2000) Consequences of changing biodiversity. Nature 405:234-242

Díaz S, Cabido M (1997) Plant functional types and ecosystem function in relation to global change. J Veg Sci 8:463-474

Díaz S, Cabido M (2001) Vive la différence: plant functional diversity matters to ecosystem processes. Trends Ecol Evol 16:646-655

Diekmann M, Falkengren-Grerup U (2002) Prediction of species response to atmospheric nitrogen deposition by means of ecological measures and life history traits. $J$ Ecol 90:108-120

Dufrene M, Legendre P (1997) Species assemblages and indicator species: The need for a flexible asymmetrical approach. Ecol Monogr 67:345-366

Ellenberg H (1996) Vegetation Mitteleuropas mit den Alpen. Eugen Ulmer, Stuttgart

Ellenberg H, Weber HE, Düll R, Wirth V, Werner W (2001) Zeigerwerte von Pflanzen in Mitteleuropa. Scripta Geobot 18:1-262

Emmett BA (1999) The impact of nitrogen on forest soils and feedbacks on tree growth. Water Air Soil Pollut 116:65-74

Flynn S, Turner RM, Dickie JB (2004) Seed information database (release 6.0, October 2004). Available at: http://www.rbgkew.org.uk/data/sid

Galloway JN, Dentener FJ, Capone DG, Boyer EW, Howarth RW, Seitzinger SP, Asner GP, Cleveland CC, Green PA, Holland EA, Karl DM, Michaels AF, Porter JH, Townsend AR, Vorosmarty CJ (2004) Nitrogen cycles: past, present, and future. Biogeochemistry 70:153-226

Gilliam FS (2006) Response of the herbaceous layer of forest ecosystems to excess nitrogen deposition. $J$ Ecol 94:1176-1191

Gower JC (1966) Some distance properties of latent root and vector methods used in multivariate analysis. Biometrika 53:325-338

Grime JP (1979) Plant strategies and vegetation processes. John Wiley \& Sons, Chichester

Grime JP (1994) The role of plasticity in exploiting environmental heterogeneity. In Caldwell MM and Pearcy R (eds) Exploitation of environmental heterogeity in plants. Academic Press, San Diego, pp 1-18

Grime JP (1998) Benefits of plant diversity to ecosystems: immediate, filter and founder effects. $J$ Ecol $86: 902-910$

Grime JP, Hodgson JG, Hunt R (1988) Comparative plant ecology - a functional approach to common British species. Unwin Hyman, London

Hector A, Schmid B, Beierkuhnlein C, Caldeira MC, Diemer M, Dimitrakopoulos PG, Finn JA, Freitas H, Giller PS, Good J, Harris R, Högberg P, Huss-Danell K, Joshi J, Jumpponen A, Körner C, Leadley PW, Loreau M, Minns A, Mulder CPH, O’Donovan G, Otway SJ, Pereira JS, Prinz A, Read DJ, Scherer-Lorenzen M, Schulze E-D, Siamantziouras A-SD, Spehn EM, Terry AC, Troumbis AY, Woodward FI, Yachi S, Lawton JH (1999) Plant diversity and productivity experiments in European grasslands. Science 286:1123-1127

Host GE, Pregitzer KS (1991) Ecological species groups for upland forest ecosystems of northwestern Lower Michigan. Forest Ecol Managem 43:87-102

Kahmen S (2004) Plant trait responses to grassland management and succession. Diss Bot 382:1-122

Keith DA, Holman L, Rodoreda S, Lemmon J, Bedward M (2007) Plant functional types can predict decade-scale changes in fire-prone vegetation. J Ecol 95:1324-1337

Kleyer M (1995) Biological traits of vascular plants. A database. Arbeitsber Inst Landschaftsplan und Ökol Univ Stuttgart 2:1-23

Klimeš L, Klimešová J, Hendriks R, van Groenendael J (1997) Clonal plant architectures: a comparative analysis of form and function. In de Kroon $\mathrm{H}$, van Groenendael J (eds) The ecology and evolution of clonal plants. Backhuys Publishers, Leiden, pp 1-29

Klotz S, Kühn I (2002) Blattmerkmale. Schriftenreihe Vegetationsk 38:119-126

Klotz S, Kühn I, Durka W (2002) BIOLFLOR - Eine Datenbank mit biologisch-ökologischen Merkmalen zur Flora von Deutschland. Schriftenreihe Vegetationsk 38:1-334

Koperski M, Sauer M, Braun W, Gradstein SR (2000) Referenzliste der Moose Deutschlands. Schriftenreihe Vegetationsk 34:1-519

Lavorel S, Garnier E (2002) Predicting changes in community composition and ecosystem functioning from plant traits: revisiting the Holy Grail. Funct Ecol 16:545-556

Loreau M, Naeem S, Inchausti P, Bengtsson J, Grime JP, Hector A, Hooper DU, Huston MA, Raffaelli D, Schmid B, Tilman D, Wardle DA (2001) Ecology - Biodiversity and ecosystem functioning: Current knowledge and future challenges. Science 294:804-808 
Mason NWH, Mouillot D, Lee WG, Wilson JB (2005) Functional richness, functional evenness and functional divergence: the primary components of functional diversity. Oikos 111:112-118

McCune B, Mefford MJ (1999) PC-ORD. Multivariate analysis of ecological data, Version 4. MjM Software Design, Gleneden Beach, Oregon

McIntyre S, Lavorel S, Tremont RM (1995) Plant life-history attributes: their relationship to disturbance responses in herbaceous vegetation. $J$ Ecol 83:31-44

Meesenburg H, Eichhorn J, Meiwes KJ (2009) Atmospheric deposition and canopy interaction. In Brumme R, Khanna PK (eds) Functioning and management of European beech ecosystems. Ecol Stud 208:265-302

Oberdorfer E (2001) Pflanzensoziologische Exkursionsflora für Deutschland und angrenzende Gebiete. Ulmer, Stuttgart

Peace WJH (1984) The interaction of light and mineral nutrient supply in the distribution of woodland herbs. Dissertation, University of Cambridge, Cambridge

Peace WJH, Grubb PJ (1982) Interaction of light and mineral nutrient supply in the growth of Impatiens parviflora. New Phytol 90:127-150

Pfadenhauer J, Poschlod P, Buchwald R (1986) Überlegungen zu einem Konzept geobotanischer Dauerbeobachtungsflächen für Bayern. Teil 1. Methodik der Anlage und Aufnahme. Ber Akad Naturschutz Landschaftspflege (Laufen/ Salzach) 10:41-60

Pillar VD (1999) On the identification of optimal plant functional types. J Veg Sci 10:631-640

Pillar VD (2004) SYNCSA 2.2.4. Available at: http://ecoqua.ecologia.ufrgs.br/

Pillar VD, Sosinski EE (2003) An improved method for searching plant functional types by numerical analysis. J Veg Sci 14:323-332

R Development Core Team (2009) R: A language and environment for statistical computing. R Foundation for Statistical Computing, Vienna

Ricklefs RE (1977) Environmental heterogeneity and plant species diversity. Amer Naturalist 111:376-381

Rogers RS (1982) Early spring herb communities in mesophytic forests of the Great-Lakes Region. Ecology 63:1050-1063

Römermann C (2006) Patterns and processes of plant species frequency and life-history traits. Diss Bot 402:1-117

Römermann C Jackel A-K, Tackenberg O, Poschlod P (2008) Eutrophication and fragmentation are related to species' rate of decline but not to species rarity! Results from a functional approach. Biodivers \& Conservation 17:591-604

Rosenzweig ML, Abramsky Z (1993) How are diversity and productivity related? In Ricklefs RE, Schluter D (eds) Species diversity in ecological communities. University of Chicago Press, Chicago, pp 62-65

Rothmaler W (2002) Exkursionsflora von Deutschland. Gefäßpflanzen. Gustav Fischer Verlag, Jena

Rothstein DE, Zak DR (2001) Relationships between plant nitrogen economy and life history in three deciduous-forest herbs. $J$ Ecol 89:385-394

Smart SM, Robertson JC, Shield EJ, van de Poll HM (2003) Locating eutrophication effects across British vegetation between 1990 and 1998. Global Change Biol 9:1763-1774

Sonnleitner MA, Gunthardt-Goerg MS, Bucher-Wallin IK, Attinger W, Reis S, Schulin R (2001) Influence of soil type on the effects of elevated atmospheric $\mathrm{CO}_{2}$ and $\mathrm{N}$ deposition on the water balance and growth of a young spruce and beech forest. Water Air Soil Pollut 126:271-290

Tamm CO (1991) Nitrogen in terrestrial ecosystems - questions of productivity, vegetational changes, and ecosystem stability. Ecol Stud 81:1-115

Tilman D (1984) Plant dominance along an experimental nutrient gradient. Ecology 65:1445-1453

Tilman D, Pacala S (1993) The maintenance of species richness in plant communities. In Ricklefs RE, Schluter $\mathrm{D}$ (eds) Species diversity in ecological communities. University of Chicago Press, Chicago, pp 13-25

Violle C, Navas ML, Vile D, Kazakou E, Fortunel C, Hummel I, Garnier E (2007) Let the concept of trait be functional! Oikos 116:882-892

Westhoff V, van der Maarel E (1973) The Braun-Blanquet-approach. In Whittaker RH (ed) Ordination and classification of communities. Handbook of Vegetation Science 5, W. Junk Publ., The Hague, pp 617-726

Wildi O (1986) Analyse vegetationskundlicher Daten. Veröff Geobot Inst Rübel Zürich 90:1-226

Wilson JB, Agnew ADQ (1992) Positive-feedback switches in plant-communities. Advances Ecol Res 23:263-336

Wisskirchen R, Haeupler H (1998) Standardliste der Farn- und Blütenpflanzen der Bundesrepublik Deutschland. Eugen Ulmer, Stuttgart

Received: 4 April 2008 /Revised: 29 April 2009 / Accepted: 2 November 2009 /

Published online: 18 February 2010 